\title{
A RETROSPECTIVE STUDY OF COMMON BACTERIAL ISOLATES AND THEIR ANTIMICROBIAL SUSCEPTIBILITY PATTERN FROM SKIN INFECTIONS IN A TERTIARY CARE HOSPITAL IN GOA
}

\author{
Urvi Kamat ${ }^{1}$, Rakhi Ghodge ${ }^{2}$
}

${ }_{1}^{1}$ Postgraduate Student, Department of Microbiology, Goa Medical College, Goa.

${ }^{2}$ Associate Professor, Department of Dermatology, Venereology and Leprosy, Goa Medical College, Goa.

ABSTRACT
BACKGROUND
The aim of this study is to analyse the pattern of common bacterial isolates and to study the antimicrobial susceptibility pattern of
these isolates from skin infections.

\section{MATERIALS AND METHODS}

This observational study was conducted using the skin swab culture and sensitivity reports collected retrospectively from the records maintained in the Department of Dermatology, Venereology and Leprosy over a period of one year from January 2015 to December 2015 in our hospital.

\section{RESULTS}

During the study, 361 non-repeat culture positive reports were analysed. Staphylococcus aureus (55.1\%) was the most common organism isolated followed by Pseudomonas aeruginosa (11.9\%). Other isolates include the species of CONS, Beta haemolytic Streptococcus, Escherichia coli, Acinetobacter, Enterobacter, Klebsiella, Proteus and Serratia. High sensitivity rates were observed against Linezolid (98.4\%) in case of gram positive cocci and against Meropenem (80.1\%) for gram negative bacilli in our study.

\section{CONCLUSION}

In order to prevent resistance against antibiotics, antibiotic stewardship program should be an integral part of every hospital setting.

\section{KEYWORDS}

Skin Swab Culture, Skin Infections, Antibiotic Susceptibility.

HOW TO CITE THIS ARTICLE: Kamat U, Ghodge R. A retrospective study of common bacterial isolates and their antimicrobial susceptibility pattern from skin infections in a tertiary care hospital in Goa. J. Evolution Med. Dent. Sci. 2017;6(2):114-117, D0I: 10.14260/Jemds/2017/29

\section{BACKGROUND}

In recent years, skin infections particularly due to multidrug resistant pathogens are increasingly being encountered in a hospital setting.[1] Skin infections contribute to increase in the cost of medical care, longer hospital stay, increase in morbidity and have a significant role in the development of antimicrobial resistance.[2]

The superficial skin infections commonly encountered are of bacterial origin and the examples include folliculitis, cellulitis, carbuncle, furuncle, impetigo and erysipelas.[3] These infections are frequently treated with either topical or oral antibiotics. [3],[4]

The commonly prescribed antibiotics are rendered resistant due to emergence of Methicillin Resistant and Vancomycin Resistant Staphylococcus aureus as well as ESBL producing and multi-drug resistant gram negative organisms in the community.

Financial or Other, Competing Interest: None.

Submission 30-11-2016, Peer Review 24-12-2016,

Acceptance 30-12-2016, Published 05-01-2017.

Corresponding Author:

Dr. Urvi Kamat,

E-9, Aquem Alto,

Behind Pandava Chapel,

Margao- 403601,

Goa.

E-mail: urvikamat@gmail.com

DOI: $10.14260 /$ jemds $/ 2017 / 29$

\section{(c) $(1)$}

It is crucial to monitor the changing trends in bacteria causing skin infections and their antimicrobial susceptibility pattern to provide suitable antimicrobial therapy for curbing infection, reducing morbidity and ameliorate the quality of life.[3]

The present study was undertaken to analyse the pattern of bacterial pathogens isolated from patients attending the O.P.D. as well as admitted to the ward and their antimicrobial susceptibility from skin swab culture reports in a tertiary care hospital.

\section{MATERIALS AND METHODS}

This retrospective study was conducted in the Department of Dermatology, Venereology and Leprosy. The records of 361 non-repeat culture positive samples were retrieved from the Department of Microbiology of this Institution over a period of one year from January 2015 to December 2015.

\section{Inclusion Criteria}

Single and mixed (only two organisms) growth showing Gram positive as well as Gram negative organisms were included in this study.

\section{Exclusion Criteria}

Mixed growth showing three or more organisms were excluded from the study.

All the bacterial isolates were identified and studied according to the standard procedures followed in the Microbiology Laboratory. ${ }^{[5]}$ 
Antimicrobial susceptibility testing was performed according to the Clinical and Laboratory Standards Institute (CLSI) guidelines using the Kirby-Bauer disk diffusion technique.[6] The antibiotics evaluated were Linezolid (30 $\mu \mathrm{g})$, Trimethoprim-Sulfamethoxazole $\quad(1.25 / 23.75 \quad \mu \mathrm{g})$, Clindamycin $(2 \mu \mathrm{g})$, Azithromycin $(15 \mu \mathrm{g})$, Ampicillin $(10 \mu \mathrm{g})$, Levofloxacin $(5 \mu \mathrm{g})$ and Vancomycin $(30 \mu \mathrm{g})$ for gram positive cocci, whereas Gentamicin (10 $\mu \mathrm{g})$, Amikacin $(30 \mu \mathrm{g})$, Piperacillin/Tazobactam $(100 / 10 \mu \mathrm{g})$, Meropenem $(10 \mu \mathrm{g})$, Ceftazidime $(30 \mu \mathrm{g})$ and Cefepime $(30 \mu \mathrm{g})$ for gram negative bacilli. The data was analysed using SPSS software version 22.0 and the results were obtained as percentages.

\section{RESULTS}

Out of the 361 samples yielding bacteria on culture, $85.6 \%$ i.e. 309 samples had monomicrobial aetiology, while in 52 cases $(14.4 \%)$, more than one organism was obtained on culture.
The most frequent bacterial combination in polymicrobial aetiology cases was one gram positive cocci and one gram negative bacilli.

As depicted in [Figure 1] gram positive cocci accounted for $70.1 \%$, while Gram Negative Bacilli (GNB) accounted for $29.9 \%$ of the total. The predominant bacterial pathogen isolated was Staphylococcus aureus (55.12\%) followed by Pseudomonas aeruginosa (11.9\%).

The sensitivity of Staphylococcus aureus was $98.4 \%$ for Linezolid, $\quad 82.1 \%$ for Clindamycin, $45.8 \%$ for Trimethoprim/Sulfamethoxazole and 25\% for Azithromycin [Table 1].

The overall sensitivity of the GNB was maximum against Meropenem (80.1\%) followed by Piperacillin/Tazobactam $(68.5 \%)$, whereas a low level of sensitivity was noted against the cephalosporins i.e. $36.4 \%$ for Ceftazidime and $41 \%$ for Cefepime [Table 2].

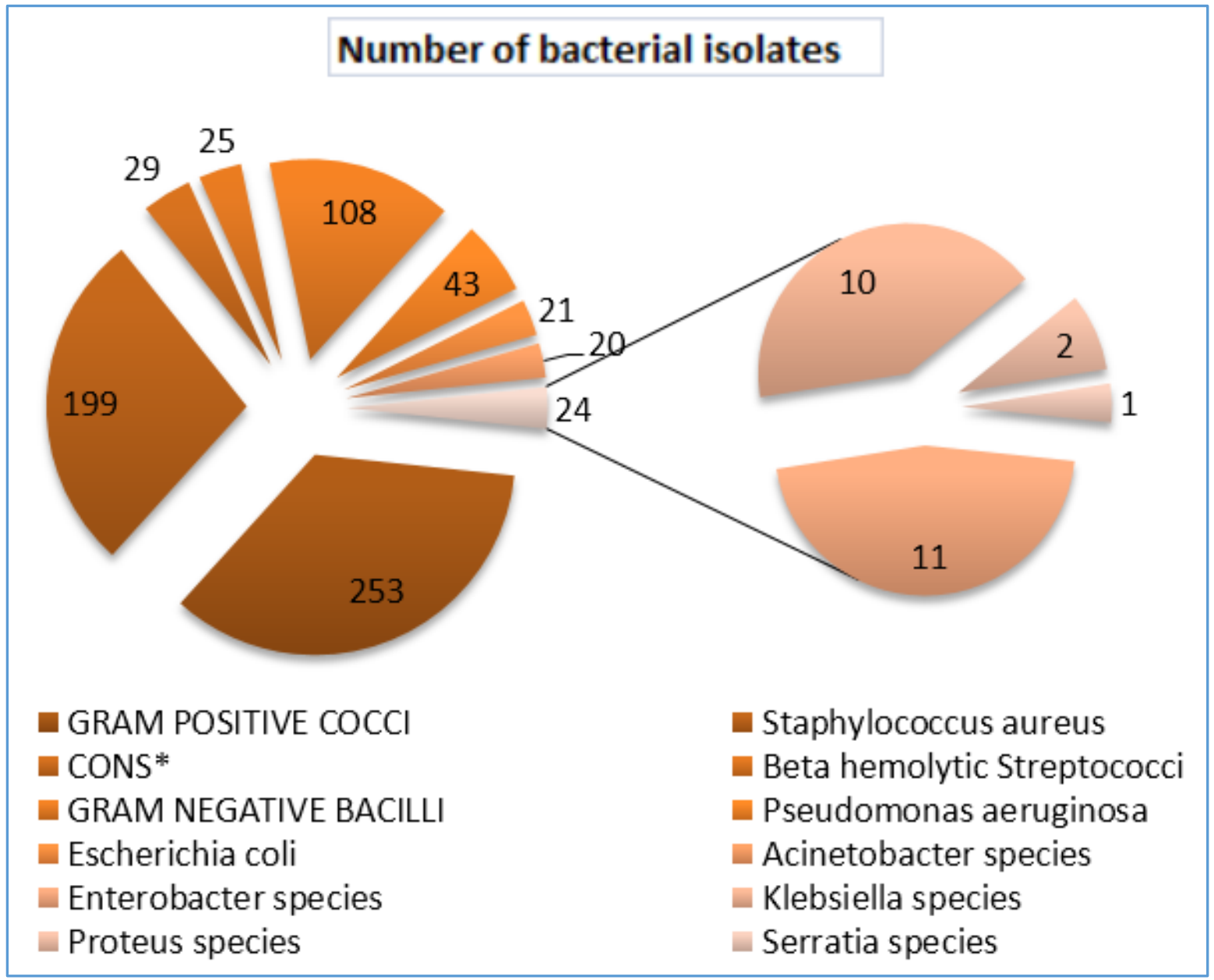

Figure 1: Bacterial Pathogens Isolated

${ }^{*}$ CONS $=$ Coagulase Negative Staphylococcus

\begin{tabular}{|c|c|c|c|c|c|c|c|}
\hline \multirow{2}{*}{ Bacterial Isolate } & \multicolumn{7}{|c|}{ \% Sensitivity } \\
\cline { 2 - 8 } & Linezolid & Clindamycin & Azithromycin & $\begin{array}{c}\text { Trimethoprim/ } \\
\text { Sulfamethoxazole }\end{array}$ & Ampicillin & Vancomycin & Levofloxacin \\
\hline St. aureus* & 98.4 & 82.1 & 25 & 45.8 & - & - & - \\
\hline CONS $^{* *}$ & 96.8 & 76.7 & 30 & 40.7 & - & - & - \\
\hline $\begin{array}{c}\text { Beta Haemolytic } \\
\text { Streptococci }\end{array}$ & 100 & - & - & - & 64.3 & 100 & 86.8 \\
\hline \multicolumn{7}{|c|}{ Table 1. Antibiotic Susceptibility Pattern of Gram Positive Cocci } \\
\hline
\end{tabular}

${ }^{*}$ Staphylococcus aureus ${ }^{* *}$ Coagulase Negative Staphylococcus. 


\begin{tabular}{|c|c|c|c|c|c|c|c|}
\hline \multirow{2}{*}{ Bacterial Isolate } & \multicolumn{7}{|c|}{ \% Sensitivity } \\
\cline { 2 - 8 } & Amikacin & Gentamicin & Levofloxacin & Ceftazidime & Cefepime & $\begin{array}{c}\text { Piperacillin/ } \\
\text { Tazobactam }\end{array}$ & Meropenem \\
\hline $\begin{array}{c}\text { Pseudomonas } \\
\text { aeruginosa }\end{array}$ & 50.1 & 52.3 & 57 & 28.1 & 30.5 & 60.2 & 78.1 \\
\hline $\begin{array}{c}\text { E. coli* } \\
\text { Acinetobacter } \\
\text { species }\end{array}$ & 72.8 & 70.4 & 68.2 & 50.2 & 50.3 & 80.4 & 90.2 \\
\hline $\begin{array}{c}\text { Enterobacter } \\
\text { species }\end{array}$ & 73.7 & 73.9 & 37 & 22 & 22.5 & 38 & 47 \\
\hline Others** & 71.9 & 72 & 69.5 & 48.8 & 53.3 & 81.6 & 93.3 \\
\hline Total & $\mathbf{6 1 . 8}$ & $\mathbf{6 2 . 2}$ & $\mathbf{5 9 . 6}$ & $\mathbf{3 6 . 4}$ & $\mathbf{4 1}$ & $\mathbf{6 8 . 5}$ & $\mathbf{8 0 . 1}$ \\
\hline \multicolumn{7}{|c|}{ Table 2. Antibiotic Susceptibility Pattern of Gram Negative Bacilli } \\
\hline
\end{tabular}

*Escherichia coli, **others include species of 'Klebsiella, Proteus and Serratia.'

\section{DISCUSSION}

Among the reports obtained from skin swab culture, it is evident that the gram positive cocci $(70.1 \%)$ were the commonest cause of superficial skin infections as compared to the gram negative bacilli (29.9\%) which was in concordance with other studies.[1],[7] Afroz et al (2015)[3] observed a lower prevalence of GPC $(42.6 \%)$ as compared to GNB (57.4\%). The predominant organism was found to be Staphylococcus aureus $(55.1 \%)$. This finding is in agreement with the works of Gupta et al (2008) ${ }^{[1]}$ and Miller et al (2015),[8] whereas Rameshkannan et al (2014) ${ }^{[9]}$ opined that E. coli was the commonest isolate from pus culture reports. All the Staphylococcus isolates including CONS were highly sensitive to Linezolid (97.6\%) as well as Clindamycin (79.4\%), which is similar to the previous studies in India[9],[10],[11] and abroad.[12],[13] Beta haemolytic Streptococci were $100 \%$ sensitive to Linezolid and Vancomycin, which is in par with the results of Sader et al (2016).[13]

The predominant GNB isolated from our study were Pseudomonas aeruginosa and E. coli. These results are similar to the studies conducted by other workers.[2],[3],[14],[15],[16] Sensitivity of Pseudomonas to Meropenem (78.1\%) and Piperacillin/Tazobactam (60.2\%) is in accordance with the results of Afroz et al (2015)[3] and Tärnberg et al (2016).[17] Escherichia coli exhibited similar rates of sensitivity to Meropenem and Piperacillin/Tazobactam as compared to previous studies.[8],[18] However, Rameshkannan et al (2014)[9] encountered $67 \%$ of resistance against cephalosporins, which is similar to the rate from our study (61.3\%).

\section{CONCLUSION}

Our analysis yields significant data of bacterial spectra and antimicrobial susceptibility in a tertiary care hospital setting in Goa. The predominant pathogens being Staphylococcus aureus and Pseudomonas aeruginosa showed a high degree of sensitivity to Linezolid and Meropenem respectively. The high diversity of the bacterial pathogens poses a challenge in the practical use of antibiotics and use of broad-spectrum antibiotics on widespread basis favours the pathogens due to selective survival advantage. Therefore, antimicrobial stewardship programs should be inculcated in every hospital setting.

\section{REFERENCES}

[1] Gupta V, Datta P, Singla N. Skin and soft tissue infection: frequency of aerobic bacterial isolates and their antimicrobial susceptibility pattern. J Assoc Physicians India 2008;56:389-90.

[2] Mohanty S, Kapil A, Dhawan B, et al. Bacteriological and antimicrobial susceptibility profile of soft tissue infections from Northern India. Indian J Med Sci 2004;58(1):10-5.

[3] Afroz Z, Metri B, Jyothi P. Bacteriological profile and antimicrobial susceptibility pattern of skin and soft tissue infections among gram negative bacilli in a tertiary care hospital of South India. J Pharm Sci \& Res 2015;7(7):397-400.

[4] Sharif A, Sharif M, Alizargar J. Bacterial susceptibility pattern of the bacteria that cause skin and soft tissue infections to cephalexin and co-trimoxazole. Middle East Journal of Scientific Research 2014;21(4):665-8.

[5] Collee JG, Marr W. Specimen collection, culture containers \& media. In: Collee JG, Fraser AG, Marmion $\mathrm{BP}$, et al, eds. Mackey and McCartney's practical medical microbiology. 14th edn. New Delhi: Elsevier 2014:95-111.

[6] M100-S25, Performance standards for antimicrobial susceptibility testing. $25^{\text {th }}$ edn. Wayne, PA: Clinical and Laboratory Standards Institute 2015.

[7] Esposito S, De Simone G, Gioia R, et al. Deep tissue biopsy vs. superficial swab culture, including microbial loading determination, in the microbiological assessment of skin and soft tissue infections (SSTIs). J Chemother 2016;4:1-5.

[8] Miller LG, Daum RS, Creech CB, et al. Clindamycin versus trimethoprim-sulfamethoxazole for uncomplicated skin infections. $\mathrm{N}$ Engl J Med 2015;372(12):1093-103.

[9] Rameshkannan S, Nileshraj G, Rameshprabhu S, et al. Pattern of pathogens and their sensitivity isolated from pus culture reports in a tertiary care hospital, Puducherry. Indian Journal of Basic and Applied Medical Research 2014;4(1):243-8.

[10] Shittu AO, Kolawole DO, Oyedepo EAR. A study of wound infections in two health institutions in ILE-IFE, Nigeria. Afr J Biomed Res 2002;5(3):97-102. 
[11] Verma P. Antibiotic sensitivity treatment for gram positive bacteria isolated from pus sample. Bull Environ Pharmacol Life Sci 2012;1(10):3-6.

[12] Alabi AS, Frielinghaus L, Kaba H, et al. Retrospective analysis of antimicrobial resistance and bacterial spectrum of infection in Gabon, Central Africa. BMC Infectious Diseases 2013;13:455.

[13] Sader HS, Flamm RK, Mendes RE, et al. Antimicrobial activities of ceftaroline and Comparator agents against bacterial organisms causing bacteremia in patients with skin and skin structure infections in U.S. medical centers, 2008 to 2014. Antimicrobial Agents and Chemotherapy 2016;60(4):2558-63.

[14] Kumar MS, Lakshmi V, Rajagopalan R. Occurrence of Extended spectrum beta lactamase among enterobacteriaceae species isolated at a tertiary care institute. Indian J Med Microbiology 2006;24(3):20811.
[15] Gangurde N, Mane M, Phatale S. Prevalence of multidrug resistant enterococci in a tertiary care hospital of India: a growing threat. Open J Med Microbio 2014;4(1):11-15.

[16] Zargar A, Masoodi S, Laway B, et al. Ciprofloxacin in the management of soft tissue infections in diabetes mellitus. J Assoc Phys India 2000;48:757-8.

[17] Tärnberg M, Nilsson L, Dowzicky MJ. Antimicrobial activity against a global collection of skin and skin structure pathoegens: results from the Tigecycline Evaluation and Surveillance Trial (T.E.S.T.), 20102014. International Journal of Infectious Diseases 2016;49:141-8.

[18] Rao R, Basu R, Biswas DR. Aerobic bacterial profile and antimicrobial susceptibility pattern of pus isolates in a south Indian tertiary care hospital. IOSR-JDMS 2014;13(3):59-62. 